\title{
Introduction: the role of central banks in economic development with an emphasis on the recent Argentinean experience
}

\author{
Mercedes Marcó del Pont \\ President, Banco Central de la República Argentina (BCRA), Argentina
}

\begin{abstract}
Almost all of the papers presented in this special issue were part of the annual conferences of the Banco Central de la República Argentina (BCRA) during the last couple of years, or are variations on the topics on which the authors presented during the Bank's Annual Conference. They share a common theme, one that is relevant for the recent Argentinean experience, but that is also important for many developing countries, since it puts into question the role of central banks in the process of development. The papers suggest that central banks historically were not limited to fighting inflation and have, under certain circumstances, been relevant in promoting a broad process of development with price stability. ${ }^{1}$ Throughout the history of central banking both in advanced and developing countries, financing governments, managing exchange rates, and supporting the productive sectors by using direct methods of intervention have been among the most important tasks of central banking and, indeed, in many cases, were among the reasons for their existence. The conventional independent central bank concerned only with inflation is, in a sense, radically out of step with the history and practice of central banking throughout most of its history.

The recent Argentinean experience, in fact, reflects this notion that central banks can be instruments of development. It is important to remember that during the Convertibility period (1991-2002) the BCRA was significantly limited in its ability to act as a lender of last resort, and that a process of liberalization, deregulation and privatization, together with the fixed exchange rate, resulted in unsustainable current account deficits and increasing external indebtedness which led to the default. After the crisis, and particularly after 2003, the economy grew at the highest rates in its recorded history, to a great extent as a result of the expansion of domestic demand.

Even though the external conditions were favorable, it is important to note that other countries in South America had a more favorable shock to their terms of trade and still grew considerably less than Argentina. Further, the expansion of demand, and the reduction of unemployment rate from more than 22 percent to around 7 percent, went hand in hand with the maintenance of primary fiscal surpluses, ${ }^{2}$ and higher real wages that permitted a considerable improvement in income distribution.
\end{abstract}

1. On the historical evolution of central banks and a discussion of their different roles over time, see Epstein (2006) and Goodhart (2010).

2. Financial deficits were only recorded after the Global Financial Crisis (GFC) and the collapse of international trade impacted the Argentine economy. Note that these deficits were caused by the use of counter-cyclical policies, which have been recommended by several economists, contrasting with the austerity policies followed in other regions. Ocampo (2011), for example, has praised the Latin American countries for having broken new ground with their performance during the GFC with their counter-cyclical policies. 
Higher growth, current account surpluses, and the accumulation of foreign exchange rate reserves, together with a tough renegotiation of the foreign debt, resulting in its reduction, in an improvement in the country's external sustainability. The Central Bank played an important role in promoting the re-monetization of the economy in the aftermath of the crisis, providing liquidity for a banking sector that expanded the credit to the private sector. Further, the Central Bank provided support to the Treasury, by extending advances on fiscal revenue, and providing part of its foreign exchange reserves to pay the external commitments of the Treasury, holding bonds in exchange.

Note that the advances to the government did not imply current account deficits, and were instrumental in allowing the economy to make a relatively large recovery from the 2009 effects of the GFC. ${ }^{3}$ It is important to emphasize that while external conditions were favorable, with the price of commodities increasing significantly, that does not mean that the economy grew as a result of good luck. In fact, inflows associated with the commodity boom put pressure on the real exchange rate and created difficulties for the process of re-industrialization, which are typical of the problems caused by the so-called Dutch Disease.

Many of the positive developments in the last decade were possible because the BCRA recovered the ability to pursue an autonomous monetary policy. The process culminated with the change of the Organic Law that regulates the actions of the BCRA, moving away from a single mandate to preserve the value of money, to the pursuit of multiple mandates associated with financial stability, employment creation, and economic development with social equity. Among the concrete measures that came from the new policy stance of the BCRA is the extension of lines of credit to productive activity, requiring that banks lend at least 5 percent of their deposits on long-term investment projects at a fixed interest rate.

In other words, the BCRA has been an integral part of an economic development strategy that prioritizes the creation of domestic jobs and the expansion of domestic markets associated with the structural transformation of the economy, while at the same time improving income distribution. This strategy has avoided the conventional wisdom obsession with inflation as the single goal of economic policy, and has steered clear of the austerity policies that have led to a slow recovery from the Global Financial Crisis in advanced economies.

In that sense, the Argentinean success since the 2001-2002 crisis underscores the relevance of dismissing the orthodox canons on how to deal with the GFC. In particular it is important, given the recent crisis in advanced economies, which owes a great deal to the worsening income distribution of the last 3 decades that led to excessive private borrowing and a financial collapse, that policies that promote inclusive strategies of development would also promote financial stability. ${ }^{4}$ An important lesson that Argentina also highlights is the importance of better income distribution to push a healthy recovery. The rest of the introduction briefly describes the contributions to this special issue of the Review of Keynesian Economics (ROKE).

3. It is important to note that now even the International Monetary Fund suggests that fiscal austerity in the face of a recession is a mistake. See, for example, Blanchard and Leigh (2013), who find that stronger planned fiscal adjustment in advanced economies has been associated with lower output growth.

4. On the relation between financial instability and income inequality, see Galbraith (2012). 


\section{THE CONTRIBUTIONS IN THIS ISSUE}

Gerald Epstein argues in his contribution that orthodoxy in central banking - that is, the idea that the most important priority goal for central banks would be to keep inflation in the low single digits - is, in general, neither optimal nor desirable. According to him, this orthodoxy is based on several false premises: namely, that moderate rates of inflation have high costs, that in this low-inflation environment economies naturally perform best, and, last but not least, that there are no viable alternatives to this inflationfocused monetary policy. He suggests that central banks can pursue several other goals, besides low and stable inflation rates, as the targets of their policies, including employment, real GDP growth, the rate of investment, and a stable and competitive exchange rate, since the latter might be related to employment creation and economic growth.

Arguably, in some respects, by pursuing alternative goals central banks might actually make the task of maintaining stable prices easier, since in many cases inflationary pressures arise as the result of supply side constraints associated with the inelasticity of foodstuff or energy-related commodities, and by promoting the development of productive forces in those sectors the central bank might lift the constraints. Further, Epstein argues that this is exactly what central banks have done, to a great extent, throughout history.

The three subsequent papers by Jane Knodell, William E. McColloch and Valerio Cerretano show particular historical circumstances in which unorthodox policies were essential for promoting economic development in a few developed economies, namely in the United States (US), the United Kingdom (UK), and Italy. Knodell argues that early US central banks, the First and Second Banks of the United States, were created to provide public finance support to the Treasury, not to deal with banking instability problems. As she argues, their functions as fiscal agents for the US government were front and center in their charters, which were mute as to these banks' monetary stabilization purposes. Yet, as she demonstrates, the public finance and fiscal functions of the First and Second Banks inevitably positioned these institutions to play a regulatory role vis-à-vis the state-chartered banks and to take actions to protect and preserve the nation's stock of specie, which represented both outside money for the domestic banking system and the means for maintaining the US government's position as an international borrower. ${ }^{5}$ Her paper highlights the importance of central banks as fiscal agents of the government and how, historically, inflation was not the main preoccupation of central banking.

McColloch contends that the adverse impact of financial regulation and state borrowing in eighteenth-century Britain, as defended by Temin and Voth (2013), has been greatly overstated. His paper briefly outlines the historical context in which the Bubble Act emerged after the infamous South Sea Bubble, before turning to analyse the existing diversity of perspectives on the Act's lasting impact. McColloch argues that there is little evidence to support the view that the Bubble Act significantly restricted firms' access to capital, and suggests accordingly that the crowding-out argument, theoretical

5. Note that Knodell (2004) has shown that countries without central banks in the nineteenth century actually grew faster than those with established monetary authorities. In addition, according to her, the US might have had the best of both worlds, with stability provided by the Bank of England, as part of the Gold Standard global monetary system, and a certain flexibility associated with Andrew Jackson's veto of the federal rechartering of the Second Bank in July 1832. 
shortcomings aside, is largely inapplicable to eighteenth-century British economic development. Finally, McColloch argues emphatically that the savings-constrained vision of British capital markets significantly downplays the extent to which the Bank of England, founded as an institution to manage the public debt in the same vein as Knodell suggests for the US Banks, provided the entire financial system with liquidity in the eighteenth century.

It is important to note the relevance of the topic for more recent discussions about the role of financial markets in the process of development. The paper suggests that financial regulation to control speculation is perfectly compatible with a significant expansion of liquidity and higher growth associated with the structural transformation of the economy. In the case under discussion, the structural transformation would be the Industrial Revolution in Britain. But the argument is essentially true of the financial regulations imposed in the US after the Great Depression, in particular the famous Glass-Steagall Act, and the widespread use of capital controls after World War II. In the last decade the discussion on capital controls, which have been adopted in Argentina as a macro-prudential tool, which together with foreign reserve accumulation provides a buffer against financial crises without necessarily becoming a restriction to economic growth or financial development, has again become relevant.

The paper by Cerretano follows the historical approach of the previous ones, arguing that central banks in developed countries became involved with industry in the past, particularly during the inter-war period. Cerretano describes the cases of Italy and Britain where central banks provided long-term finance to ailing firms and banks, becoming important industrial players in their countries. His article explores the episode in a comparative setting, and concludes that intervention did not stem from a grand design of policy or from anti-market ideologies, but rather was piecemeal and a consequence of financial austerity. He also argues that intervention was the outcome of the over-expansion of the heavy industries more than the consequence of the weakness of financial systems. Likewise, Cerretano indicates that the Italian and British experiences also seem to point out that the direct management of ailing firms and banks proved more efficient and acceptable for central banks than the continuous provision of funds to economic groups whose managers were strangers to the central banks' bureaucracy.

The last two papers, by Juan Matías De Lucchi and by Esteban Pérez Caldentey and Matías Vernengo, move away from the more purely historical analysis of central banking and discuss the limitations of orthodox policies, in particular the currency board option adopted by Argentina in 1991, under the guise of the so-called Convertibility Plan, and the inflation-targeting approach adopted by several economies around the globe. In this sense, they complement the previous contributions by showing that current orthodox practices not only depart from the practical historical record on central banking, but also have dangerous consequences for the process of economic development.

De Lucchi shows that the explanation of the endogeneity of money during the Argentinean currency board is compatible with the heterodox endogenous money approach. The Argentinean Convertibility was interpreted in the conventional view as a pure case of the Mundell-Fleming model with fixed exchange rate (MFFER). This approach points out that domestic money supply becomes endogenous because the Central Bank loses the ability to control the monetary aggregates. In the MFFER, money endogeneity is supplyled, and results from a balance of payment effect, in other words, from the rule that says that for every dollar inflow there will be a domestic issuance, and that monetary destruction will follow outflows. The heterodox approach, on the other hand, is demand-led, resulting 
from a bank credit effect. The central bank had some flexibility in the creation of reserves, according to private banks' credit demands, but it still had a dollar shortage problem, which in the absence of current account surpluses could only be compensated by borrowing in international markets. In other words, De Lucchi correctly suggests that, given the structural external constraint, the BCRA operated as a lender of last resort to an unsustainable expansion of public foreign indebtedness. It is important to note that it is this unsustainable pattern of behavior that the new Organic Law has superseded, emphasizing the importance of credit creation in domestic currency.

Finally, Pérez Caldentey and Vernengo argue that the justification for inflation targeting rests on three core propositions, none of which can be sustained after close scrutiny. The first proposition is called 'lean against the wind', which refers to the fact that the monetary authority contracts (expands) aggregate demand below capacity when the actual rate of inflation is above (below) target. The second one is 'the divine coincidence', which means that stabilizing the rate of inflation around its target is tantamount to stabilizing output around its full employment level. The third proposition is that of stability. This means that the inflation target is part of an equilibrium configuration which generates convergence following any small disturbance to its initial conditions. These propositions are derived from a closed economy setting which is not representative of the countries that actually have adopted inflation targeting frameworks, and the authors suggest that even if one uses the conventional logic, an open environment setting shatters the validity of the three propositions mentioned above.

Currently there are 27 countries, 9 of which are classified as industrialized and 18 as developing, that have explicitly implemented a fully-fledged inflation-targeting regime. These countries are open economies and are concerned with the evolution of the external sector and the exchange rate as proven by their interventions in the foreign exchange markets. The trade-offs faced by central banks in open economies are significantly more complex than those suggested by the inflation-targeting model, and reliance on this regime should be taken with extreme caution, given the unreliability of its empirical results.

It is often the case that orthodoxy in matters of policy becomes controversial in periods of crises. The Great Depression was one such situation, and the current Global Financial Crisis seems to fit the bill too. The experiences discussed in the papers gathered here shows that unorthodox solutions have from time to time allowed the world economy to avoid the suffering that comes with monetary policies that are only concerned with inflation and fiscal rectitude. As Keynes famously argued, worldly wisdom suggests that 'it is better for reputation to fail conventionally than to succeed unconventionally,' but there is more than reputation to central banking.

\section{REFERENCES}

Blanchard, O. and D. Leigh (2013), 'Growth Forecast Errors and Fiscal Multipliers,' IMF Working Paper No 13/1.

Epstein, G. (2006), 'Central Banks as Agents of Economic Development,' UNU-WIDER, Research Paper No 2006/54.

Galbraith, J.K. (2012), Inequality and Instability: A Study of the World Economy Just Before the Great Crisis, New York: OUP.

Goodhart, C. (2010), 'The Changing Role of Central Banks,' Bank of International Settlements, Working Paper No 326. 
272 Review of Keynesian Economics, Vol. 1 No. 3

Knodell, J. (2004), 'Central Banking in Early Industrialization,' in M. Lavoie and M. Seccareccia (eds), Central Banking in the Modern World: Alternative Perspectives, Cheltenham: Edward Elgar, pp. 262-281.

Ocampo, J.A. (2011), 'Macroeconomy for Development: Countercyclical Policies and Production Sector Transformation,' CEPAL Review, 104, 7-35.

Temin, P. and H.-J. Voth (2013), Prometheus Shackled: Goldsmith Banks and England's Financial Revolution After 1700, Oxford: OUP. 